\title{
A Debt of Gratitude
}

Dear Reviewer,

My heartfelt greetings to you for a joyous year of life and work and deep appreciation of your painstaking contributions in sustaining the editorial standards of the Indian Academy Proceedings in Earth and Planetary Sciences.

Vinod K Gaur

Editor

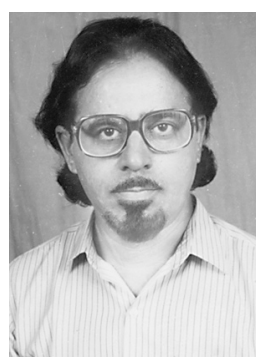

Bimulendu B Bhattacharya, is Professor and Head, Department of Applied Geophysics of Indian School of Mines, Dhanbad, and is currently the Director-in-charge. His major research interests include electrical, electromagnetic, magnetotelluric methods (MT) of interpretations and 2D \& 3D modelling.

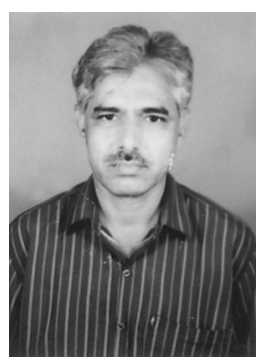

Narayan B Bhosle, is a scientist at the National Institute of Oceanography, Dona Paula, Goa. His major research interests are biofilm, microbially induced corrosion, exopolysaccharides and biochemistry.

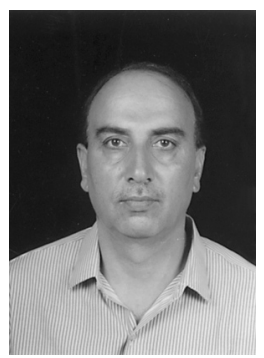

S K Bhushan, is Director (SG) at the Geological Survey of India, Jaipur. His major interest in the last three decades has been neoproterozoic malani bimodal volcanism and lithostratigraphy of Rajasthan.

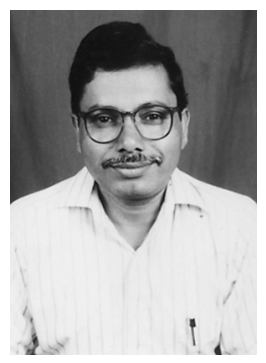

B N Goswami, is Professor at the Centre for Atmospheric and Oceanic Sciences, Indian Institute of Science, Bangalore. His major research interests are large scale air-sea interactions in the tropics, dynamics of tropical variability and predictability of climate in general and Indian monsoon in particular.

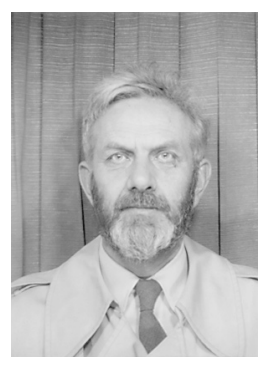

Peter R Hooper, is Professor Emeritus in the Department of Geology, Washington State University, Pullman, Washington, U.S.A. He is an igneous petrologist with a special interest in continental flood basalts (Columbia River, Deccan, Karoo), their tectonic setting, and the use of rapid chemical analyses for major and trace elements characterization of individual eruptive events.

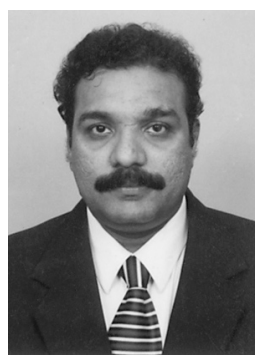

A Jayaraman, is an Associate Professor in the Planetary Atmospheres and Aeronomy Sciences Division, Physical Research Laboratory, Ahmedabad. His major research interests are characterization of atmospheric aerosols by different air-borne and ground-based measurement techniques and investigation of aerosol radiation interaction in the atmosphere and particularly the radiative forcing by aerosols and its role in climate change.

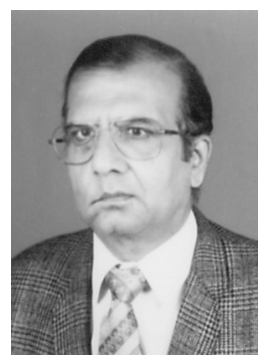

A K Kamra, is Deputy Director at the Indian Institute of Tropical Meteorology, Pune. His current research interests include cloud electrification and its effects on the microphysical properties of the clouds, the global electric circuit, the fair weather atmospheric electricity and the physical characteristics and the transportation of atmospheric aerosols.

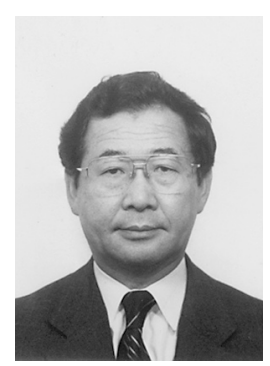

I. Kaneoka, is a Professor and the Division Chief of Global Dynamics at the Earthquake Research Institute, University of Tokyo. His researchers include the evolution and the chemical structure of the Earth, the state of volatile elements in the earth's deep interior and the volcanism on large scale, based on noble gas isotopes and geochronological methods.

Proc. Indian Acad. Sci. (Earth Planet. Sci.), 109, No. 4, December 2000, pp. 1-6

(C) Printed in India 


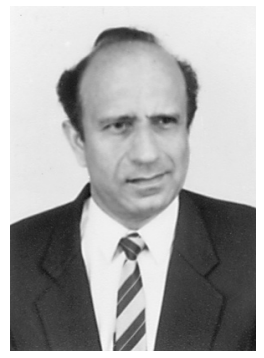

Naresh Kochhar, is a Professor at the Center of Advanced Studies in Geology, Punjab University, Chandigarh. His main research interests include mantle plume related anorogenic malani magmatism vis-a-vis assembly of a late proterozoic supercontinent.
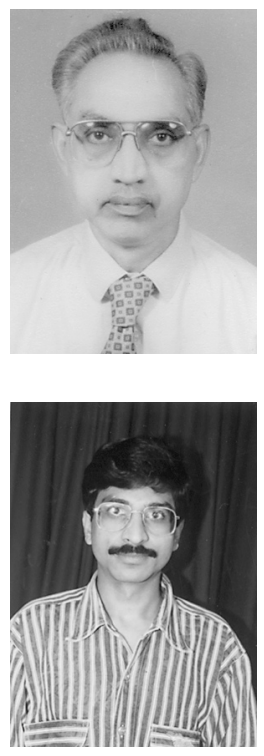

M R Madhav, is a professor of civil engineering at IIT, Kanpur. He has developed a new approach of dealing with difficult ground conditions, appropriately called 'Doctoring of Ground' and is currently working in modelling and analysing various ground improvement technologies.

Ajay Manglik, is a scientist at the National Geophysical Research Institute, Hyderabad. His research interests include lithospheric and mantle dynamics, thermal modeling, and joint inversion of geophysical data.

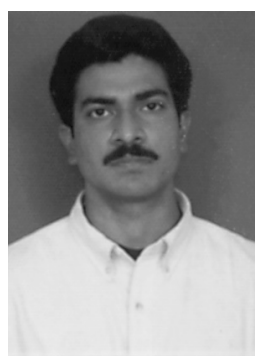

Aninda Mazumdar, is working as a postdoctoral fellow at the Physical Research Laboratory, Ahmedabad. His research interests include phosphogenesis, rare earth element geochemistry, geochemistry and sedimentology of carbonate and black shale, illite crystallinity and low grade metamorphism, late Proterozoic and early Cambrian boundary problem.

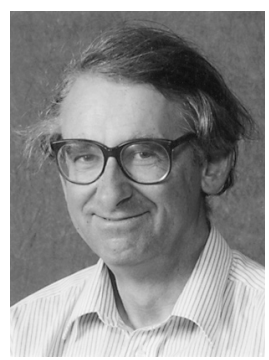

Dan McKenzie, holds a Royal Society Research Professorship in the Department of Earth Sciences, Cambridge, and his principal interests are melt generation in the earth's mantle and planetary geology.

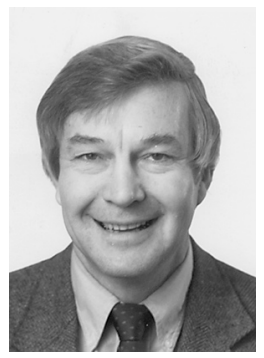

Richard W Ojakangas, is a Professor in the Department of Geological Sciences at the University of Minnesota Duluth, Duluth, Minnesota, U.S.A. His major research interests involve the sedimentology of Precambrian rocks, with emphasis on glaciogenic rocks, iron- formation, turbidites, and quartzites.

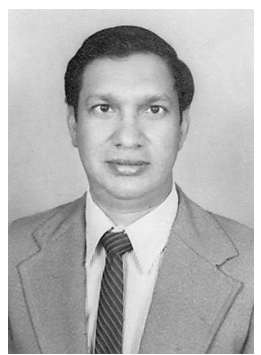

P C Pandey, is the Director of National Centre for Antarctic \& Ocean Research, Goa. His major research interests are satellite oceanography, remote sensing, satellite based atmospheric sciences and meteorology, and polar sciences.

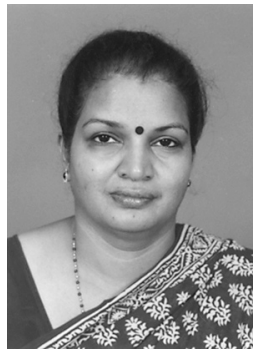

Kusala Rajendran, is a Scientist at the Centre for Earth Science Studies, Trivandrum. Her research interests include seismotectonics, mechanisms of faulting, fluid induced faulting and paleoseismology.

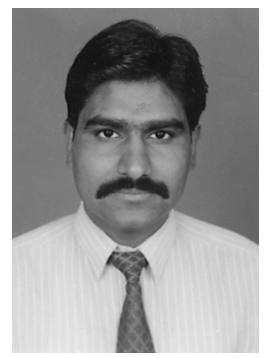

S S Rathore, is working as Dy. Suptdg. Geologist in ONGC and has research interest in geochronology. $\mathrm{He}$ has established $\mathrm{K}-\mathrm{Ar}$ and $\mathrm{Ar}-\mathrm{Ar}$ dating facilities at KDM Institute of Petroleum Exploration, Dehradun. For the last few years, he has been working on evolution of basement rocks of different sedimentary basins of India utilizing various geochronological techniques.

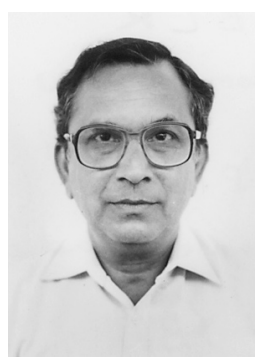

B L K Somayajulu, is Honorary Professor and CSIR Emeritus Scientist in the Oceanography \& Climate Studies Area of the Physical Research Laboratory, Ahmedabad. His current interests are ciculation in the Northern Indian Ocean using $14 \mathrm{C}$ and $\mathrm{Ra}$ isotopes, understanding paleoclimate/ paleoceanography of the same region from studies of the underlying sediments. He is also involved with the augmentation of the IOP, Bhubaneswar accelerator into AMS.

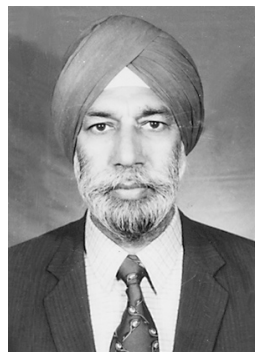

Sarva Jit Singh, is a CSIR Emeritus Scientist at Maharshi Dayanand University, Rohtak. His current research interests include modelling of coseismic and postseismic crustal deformation, propagation of elastic waves anisotropic media and seismic source studies. 


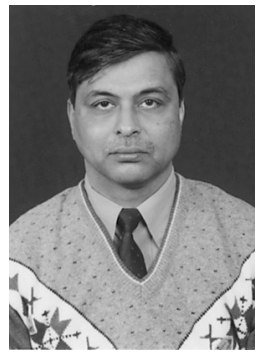

J P Srivastava, is a Reader in the Department of Geology, University of Delhi. His research interests in the past two decades has been in mineralogy and geochemistry of the Deccan volcano-sedimentary sequences. Currently, he is involved in the structural and compositional studies on the smectites and geopolymers of iridium enriched sediments and their implications on Deccan volcanism and KTB.

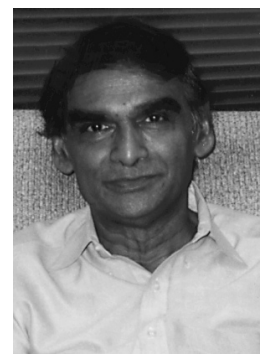

T N Krishnamurthy, is a Professor of Meteorology, tropical Meteorology. His research interests are in the following areas: high resolution hurricane forecast (tracks, landfall, and intensity), monsoon forecasts on short, medium range, and monthly time scale and studies of interseasonal and interannual variability of the tropical atmosphere. Phenomenological interests inlcude hurricanes, monsoons, jet streams, and the meteorology of arid zones.

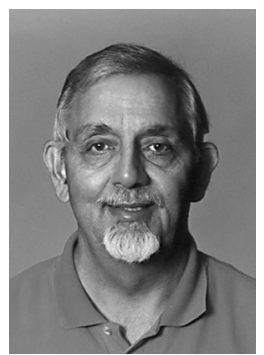

Pradeep Talwani, is a Professor of Geophysics in the Department of Geological Sciences at the University of South Carolina. His major interests include the nature of induced seismicity, mechanisms for intraplate earthquakes, paleoseismology, hydraulic properties of fractured rocks and the physics of the earthquake process.

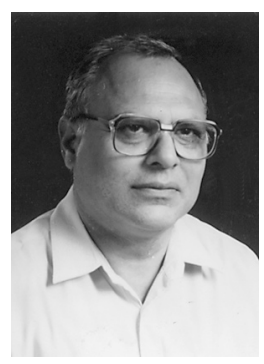

S K Tandon, is Professor at the Department of Geology, University of Delhi. His major interests are in physical stratigraphy and sedimentology with a special focus on quaternary stratigraphy and palaeoenvironments. His current interest centres on reconstruction of Late Quaternary climate of the Thar and Ganga basin.

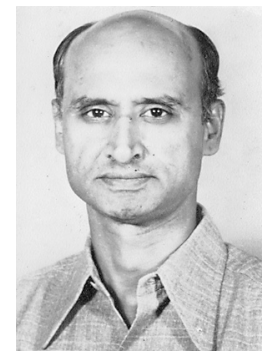

R Vaidyanadhan, was Professor at the Andhra University, Visakhapatnam and subsequently the Editor of the Journal of Geological Society of India, Bangalore. His main contributions have been in the fields of geomorphology, quaternary geology and applications of remote sensing in earth sciences.

Other referees who have reviewed papers for the journal

A K Baksi, Department of Geology, Louisiana

M S Bodas, Geologocal Survey of India, Lucknow.

R Chander, Department of Earth Sciences, Roorkee.

Chul Eddy Chung, Scipps Institute of Oceanography, California.

Somnath Dasgupta, Department of Geological Sciences, Calcutta.

S K Guha, Geological Survey of India, Calcutta.

P K Gupta, Department of Earth Sciences, Roorkee.

G S Lakhina, Indian Institute of Geomagnetism, Mumbai.

Peter Lightfoot, Sudbury Field Exploration Office, Canada.

D C Misra, National Geophysical Research Institute, Hyderabad.

Anand Mohan, Banaras Hindu University, Varanasi.

J J Mahoney, Hawaii Institute of Geophysics, Hawaii.

Asoke Mookherjee, Department of Geological Sciences, Calcutta.

Sri Niwas, Department of Earth Sciences, Roorkee.

M Ozima, Geophysical Institute, Tokyo.

K Parameswaran, Vikram Sarabhai Space Centre, Thiruvananthapuram.

C R K Radhakrishna Murthy, Department of Earth Sciences, Mumbai.

R Ramesh, Physical Research Laboratory, Ahmedabad.

A Sahni, Department of Geology, Chandigarh.

S K Sen, Calcutta.

Satheesh C Shenoi, National Institute of Oceanography, Goa.

A Sridharan, Bangalore.

K V Subbarao, Department of Earth Sciences, Mumbai.

C R Subramanya, Raman Research Institute, Bangalore. 